\title{
Scientific Literacy Ability of the Free Service Teacher
}

\author{
Muhammad Nasir ${ }^{1}$, Erviana Abdullah $^{2}$, Muhammad Nur $^{1}$, Ahmad Yani $^{1 *}$ \\ ${ }^{I}$ Biology Education Program, Faculty of Teacher Training and Education, Universitas Puangrimaggalatung \\ Sengkang, South Sulawesi, Indonesia \\ ${ }^{2}$ Administration Education Program, Faculty of Teacher Training and Education, Universitas \\ Puangrimaggalatung Sengkang, South Sulawesi, Indonesia
}

*Corresponding Author: Ahmad Yani, Biology Education Program, Faculty of Teacher Training and Education. Universitas Puangrimaggalatung Sengkang. South Sulawesi, Indonesia

\begin{abstract}
The objective of the research is to analyze the scientific literacy initial ability of biology education students in PRIMA Sengkang. The kind of research is descriptive-qualitative. This research was done in STKIP PRIMA Sengkang University in 2018/2019 academic year. The subject of the research was all the students of Biology education, specifically Anatomy and Physiology subject. The qualitative data of this study were collected through a written test then it was analyzed by using the qualitative-descriptive method. The result of the study showed that the students' scientific ability in Biology Education prima Sengkang was at a low level. The use of scope management of the given subject can be applied to overcome the students' low ability of scientific literacy.
\end{abstract}

Keywords: Biology Education, Scientific Literacy, Pre-Service Teacher

\section{INTRODUCTION}

Scientific Literacy becomes the most important thing for the learners as a preparation to face the development of 21st-century challenges. According to Treacy at al. (2010): "Scientific literacy is directly correlated with building a new generation of stronger scientific minds that can effectively communicate research science to the general public, Based on the statement above, scientific literacy is directly correlated with building a new generation that has strong scientific mind and attitude and able to communicate the result of the study effectively to the society. Those who have scientific literacy apply the scientific concept, having the scientific skill to asses and decide daily life when interacting with others.

The previous research shows that the students have difficulties to use scientific evidence dan decide social-science issues (OECD , 2006) and it is predicted because of the weakness of scientific literacy of the students. Through the real and relevant situation, scientific literacy can be developed (Dam $\&$ Volman, 2004). The real situation will motivate the students to learn about science due to they know the urgent of science in daily life. Bybee (Soobard\&Rannikmae, 2011) suggest an activity framework or just certain situation (example: When having a test), their understanding just based on textbooks that have been read. In the upper level, namely conceptual and procedural the students have understood the scientific principals and theories, understanding how to correlate each concept as the unity, understanding the process of the science and comprehend about the inquiry. While the students who can utilize some kinds of concept and have the ability to correlate these concepts with their real life, they know that science, social and technology are correlated and influenced each other. Showing that they are in a multidimensional level, (Odja\&Payu, 2014).

Based on the students' problem with scientific literacy, reading activity should be increased. The study of reading science activity and interest of Biology education PRIMA SENGKANG students is never done. Analyzing reading science activity and interest need to be realized in scientific research. It seems that theme lack of observation. The result of the study is expected to improve the students' performance in a learning activity to be science literator.

Based on the previous research, the result of the learning process of Biology education STKIP PuangrimaggalatungSengkang in many subjects still include at a low level. The low learning outcome is shown from there are some students are difficult to comprehend and analyze the learning materials. 
Haerunnisa, Yani\&Andani (2018) stated that the scientific attitude was not optimally honed as part of the scientific competence of STKIP students in PuangrimaggalatungSengkang. This has implications for the poor ability to think and analyze the results of experiments or exercises for prospective biology student teachers (Yani, Amin, Rohman, Suarsini\&Sahriah, 2019). Besides, the low learning outcomes can be seen by many students who have difficulty understanding lecture material and analyzing the lecture material provided (Yani, Haerunnisa\& Rahim, 2017).The low ability of scientific literacy of the teachers' candidate students will affect the students' learning success in the school. Besides, The low ability of scientific literacy of the teachers' candidate students will affect to a misconception of the elementary or secondary students so the study results in three aspects include cognitive, affective and psychomotor become low as well (Fazilla, 2016).

The teachers must be knowledgeable to gain talented students in scientific literacy especially in learning biology or the concept of nature and basic concept of science. In this case, teachers have the main role and interact with the students in the learning process, So that the existence of the teachers influence the result of the study. The role of teachers not only teach about the concept and the process of learning and teaching activity but also to educate and show the application of good character, attitude and habit. This case is relevant to Sagala (2008) He stated that teachers should plan and execute learning process, assess learning the result, guide and supervise, doing research and observe, communicate with wide society.

Scientific Literacy derives from two words; literature and Scientia. Literatures means letter, knowing the letters or educated. And scientia means knowing. Paul de Hart Hurt (in Adisendjaja, 2007) is the first one who introduced scientific literacy term. According to Hurt scientific literacy is acquiring science and apply it for the sake of society's needs.

Science literacy has some definitions and tends to change along with the era. According to PISA (2012), Science literacy is defined as "the capacity to use scientific knowledge to identify questions acquire new knowledge, explain scientific phenomena and draw evidence-based conclusions about science-related issues; their understanding of the characteristic features of science as a form of human knowledge and enquiry; their awareness of how science and technology shape our material, intellectual and cultural environments; and their willingness to engage in science-related issues, and with the ideas of science, as a reflective citizen. (OECD, 2013, p. 100)". In this case, science literacy based on the PISA measures three competencies which are based on the logic, intellectual and critical analysis. Those three competencies are the students who can identify science issues, explaining phenomena scientifically and using scientific pieces of evidence. Each item of science literacy question of PISA the real-life context and it's not limited by the school and the class area. PISA question focuses on a varied situation such as; ourselves and family, social and global. While scientific knowledge which is examined to PISA science literacy focuses on the knowledge of science (knowledge if the real-life) and knowledge about science (knowledge of science itself), (PISA, 2012).

PISA's research findings (Programmes for International Student Assessment) that have been done since 2000 doesn't describe satisfied result due to the average score of the students still doesn't achieve the international standard, 500 score. The average score of Indonesia students was 371 in 2000,382 in 2003.393 in 2006 . The average score of reading capability was just 405 . This result is different from the international average score. Based on that achievement, the scientific skill of Indonesian students is just inability of recognizing the basic fact, they are not able yet to communicate and correlate with others scientific topics as well as applying the concepts (Toharudin et al., 2011).

Considering the importance of the teachers' role in learning, a teacher must have useful abilities to improve the quality of education. Learning process which is done by teachers should also motivate the students to learn to gain meaningful learning. Not only the teachers but also the candidates of teachers should have good ability to present excellent teaching-learning process when being the real teachers. Therefore, teachers' candidates should be skilful and knowledgeable of science. Hence, the teachers' candidate students of Biology should have good science ability for the sake of the next generations.

\section{Materials AND Methods}

This research is descriptive. The objective of this research is to analyze the scientific literacy ability of the Biology teachers' candidate students. Sukmadinta (2011) explained that descriptive research is the research which describes all the things scientifically and based on the real situation. The research subject was all the students of Biology major particularly human anatomy and physiology subject 
The instrument to measure the ability of science literacy was a multiple-choice test. The test consisted of 15 questions based on scientific literacy indicators according to Gormally et al (2012) as follows: (1) Identify valid scientific opinion; (2)effective literature investigation;(3) understanding of the research design elements and the impact on the findings or conclusion; (4) Making a graph based on the accurate data; (5) Overcoming the problems by using quantitative skill, include basic statistic; (6) Understanding and interpreting basic statistic; (7) Doing inference, prediction and deciding conclusion based on quantitative data.

The scoring scale was 0-00 the criteria start from very poor up to very good. An assessment criterion is presented in Table 1 below. Validity assessment of the questions was done by adjusting each question to the indicator of science literacy. The result of the validity test showed that there were 15 valid questions among 29 questions. The reliability test was done by using the Quest program. The result of developed reliability test had high accuracy, 0.83 (Sukiman, 2012).

Table1. Assessment criteria of scientific literacy

\begin{tabular}{|l|l|}
\hline Interval & Kriteria \\
\hline $85-100$ & Very good \\
\hline $70-84$ & Good \\
\hline $55-69$ & Enough \\
\hline $50-54$ & Poor \\
\hline $0-49$ & Very Poor \\
\hline
\end{tabular}

(Source: Sudijono, 2006)

\section{RESULTS AND DISCUSSION}

The first step of the research was composing test of the science literacy ability and applied indicator which was adapted from Gormally et al. (2012). Afterthat, the data of the Biology students' ability of science literacy was collected by using the integrated test of science literacy indicator. Then the test was done and followed by 52 students. Scoring was done based on the students' answers and assessment criteria that had been decided. The scoring scale was 0-00. The students' score was achieved score divided by maximum score times 100 .

$$
\frac{\text { achieved score }}{\text { maximum score }} \times 100
$$

The general description of the students' science literacy ability is shown by the following table.

Table2. The students' ability of scientific Literacy

\begin{tabular}{|c|c|c|c|}
\hline No & Indicator & Score & Criteria \\
\hline 1 & $\begin{array}{l}\text { Identifying the valid } \\
\text { scientific opinion }\end{array}$ & 64 & Enough \\
\hline 2 & $\begin{array}{ll}\begin{array}{l}\text { Effective } \\
\text { investigation }\end{array} & \text { literature } \\
\end{array}$ & 78 & Good \\
\hline 3 & $\begin{array}{l}\text { Understanding of the } \\
\text { research design elements }\end{array}$ & 50 & Poor \\
\hline 4 & $\begin{array}{l}\text { Making a graph based on } \\
\text { accurate data }\end{array}$ & 64 & Enough \\
\hline 5 & $\begin{array}{l}\text { Overcoming the problems } \\
\text { by using quantitative } \\
\text { skill, include a basic } \\
\text { statistic }\end{array}$ & 54 & Poor \\
\hline 6 & $\begin{array}{l}\text { Understanding and } \\
\text { interpreting basic statistic }\end{array}$ & 58 & Enough \\
\hline 7 & $\begin{array}{l}\text { Doing inference, } \\
\text { prediction and deciding } \\
\text { conclusion based on } \\
\text { quantitative data }\end{array}$ & 60 & Enough \\
\hline
\end{tabular}

The result of the students' answers analysis shows that Doing Effective literature investigation was 78 correct answers (good). Identifying the valid scientific opinion and Making a graph based on the accurate data were at the same percentage, 64 (enough). Then Understanding and interpreting basic statistic, doing inference, prediction and deciding conclusion based on quantitative data were in the 
highest percentage, $58 \%$ and $60 \%$. Two other indicators were in the poor category those understanding of the research design elements (50) and overcoming the problems by using quantitative skill include basic statistic (54).

The average score of the students' science literacy test in Biology education-based shows few difference among the indicators based on table 2. The average score of the students' science literacy test in Biology education in this research was $61 \%$ in which enough category. It indicated that there must be learning processes which involve scientific skill process, such as composing scientific questions to do an observation, using cognitive skill to explain the natural phenomenon and also make a conclusion based on the fact that gained from observation process. (Firman, 2007).

Generally, the Biology education students' science literacy ability was in enough category. The students' scientific literacy ability is an essential problem that must be solved soon. Due to scientific literacy has the main role in our daily life. Biology education students are insisted to have a high qualification of scientific literacy. Scientific literacy ability of the candidate teachers is very influential in learning biology in the school.

The low ability of the Biology students will affect the low ability to the students in the school as well so that the students are not able to accomplish learning material deeply. The students just oriented on the final score. Whereas science literacy correlates with social interaction, correlate with people's activities of every age level, not only for children but also for a teenager as well as an adult. Lin (in Sujana, 2014) stated that Scientific literacy correlates with the society at all age levels, so it must be increased to achieve better science literacy ability.

The result of the study showed that there still some context, content and the science basic concept were not maximal yet. Some students didn't understand yet more detail concept of biology. Good Literacy ability is expected to improve Biology concept. This research emphasizes the improvement of the students' literacy ability particularly the biology candidate teachers. Not only for Biology learning process but also being an educator who can deliver knowledge to the students well.

\section{CONClusion}

The result of science literacy analysis of the Biology education Students in showed that doing Effective literature investigation was in a good category, Identifying the valid scientific opinion and Making a graph based on the accurate data were at the same category, enough. Then Understanding and interpreting basic statistic, doing inference, prediction and deciding conclusion based on quantitative data were in enough category. Next, Two other indicators were in the poor category those are understanding the research design elements and overcoming the problems by using quantitative skill include basic statistic. Generally, the Biology education students' science literacy ability was in enough category. Due to the importance of scientific literacy for the teacher candidates students so the learning method that involves science process is needed to accustom the students to apply scientific steps in learning.

\section{ACKNOWLEDGEMENT}

The author sincerely thanks the institutions that helped to realize this research. This research is supported by RISTEKDIKTI Republic of Indonesia.

\section{REFERENCES}

[1] Adisendjaja, Y. H. Analisisbuku Ajar Biologi SMA Kelas X di Kota Bandung BerdasarkanLiterasiSains. [Online].Tersedia: http://file.upi.edu/Direktori (Diakses 10 Februari 2019)

[2] Dam, G. \&Volman, M. 2004. Critical thinking as a citizenship competence: teaching strategies Learning and Instruction, 14(4), 359-379.

[3] Fazilla, Sarah. 2016. Kemampuan LiterasiSainsMahasiswa PGSD Pada Mata KuliahKonsepDasarSains. JurnalPendidikanDasar. Vol. 3, No. 2, 22-28.

[4] Firman, H. 2007. LaporanAnalisisLiterasiSainsBerdasarkanHasil PISA NasionalTahun 2006. Jakarta: PusatPenilaianBalitbangDepdiknas.

[5] Gormally, C., Peggy B., dan Mary L. 2012. Developing a Test of Scientific Literacy Skills (TOLS): Measuring Undergraduates Evaluation of Scientific Information and Arguments. CBE-Life Sciences Education, No. 11, 364-377.

[6] Haerunnisa, Yani, A., \&Andani, C. (2018). Pengembangan Bahan Ajar Berbasis Worksheet MatakuliahBiologiLautuntukMeningkatkanSikapIlmiahMahasiswa. JurnalBiotek, 6(2), 96-110. 
[7] Odja, A.H. \&Payu, C. S. 2014. AnalisisKemampuanAwalLiterasSainsSiswaPadaKonsep IPA. Jurnal Kimia FMIPA UniversitasNegeri Surabaya, 40-47.

[8] OECD. 2006. PISA 2012 Assessment and Analytical Framework: Mathematics, Reading, Science, Problem Solving and Financial Literacy. OECD Publishing.

[9] PISA. 2012. Assessment Framework Key Competencies in Reading, mathematics and science. OECD.

[10] Sagala, Syaiful. 2008. Konsepdan Makna Pembelajran. Bandung: Alfabeta.

[11] Sudijono, A. 2006. Pengantar Evaluasi Pendidikan. Jakarta: Raja Grafindo Persada.

[12] Sujana, A, dkk. 2014. Literasi Kimia Mahasiswa PGSD dan Guru IPA SekolahDasar. Jurnal Pendidikan IPA Indonesia. Vol 3 No.1.

[13] Sujionodkk. 2008. MetodePengembanganKognitif. Jakarta :Universitas Terbuka.

[14] Sukmadinata. 2011. MetodologiPenelitianPendidikan. Bandung: RemajaRosdakarya.

[15] Toharudin, Uus.,Hendrawati, Sri., Rustaman, Andrian. 2011. Membangun LiterasiSains Peserta Didik. Bandung: Humaniora.

[16] Treacy, Daniel J., Collins, Melissa S. Kosinski. 2011. Using the Writing and Revising of Journal Articles to Increase Science Literacy and Understanding in a Large Introductory Biology Laboratory Course. Atlas Journal of Science Education. 1(2): 29-37.

[17] Yani, A., Amin, M., Rohman, F., Suarsini, E., \&Sahriah. (2019). Profile of Teaching Materials Environment Biology and Ability Pre-service Biology Teacher to Communicate Laboratory Report. International Journal of Humanities Social Sciences and Education (IJHSSE), 6(3), 33-39.

[18] Yani, A., Haerunnisa, \& Rahim, S. (2017). AnalisisAktivitasdanSikapIlmiahMahasiswaMelalui Model Pembelajaran Project Based Learning (PjBL) PadaPerkuliahanBiologi Air Tawar STKIP PuangrimaggalatungSengkangSul-Sel. In Seminar Nasional III 2017 "Biologi, Pembelajaran, danLingkungan Hidup PerspektifInterdisipliner" (pp. 145-150). Malang: Universitas Muhammadiyah Malang.

Citation: Ahmad Yani, et.al. "Scientific Literacy Ability of the Free Service Teacher" International Journal of Humanities Social Sciences and Education (IJHSSE), vol 7, no. 2, 2020, pp. 1-5. doi: http://dx.doi.org/10.20431/2349-0381.0702009.

Copyright: (C) 2020 Authors. This is an open-access article distributed under the terms of the Creative Commons Attribution License, which permits unrestricted use, distribution, and reproduction in any medium, provided the original author and source are credited. 